\title{
WATER QUALITY INDEX IN TIGRIS RIVER WITHIN BAGHDAD CITY
}

\author{
${ }^{*}$ Noor Q. Ahmed ${ }^{1}$
}

Karim R. Gubashi ${ }^{2}$

1) Department Environmental Engineering, Mustansiriyah University, Baghdad, Iraq

2) Assist prof. Dr. Mustansiriyah University, Baghdad, Iraq

\begin{abstract}
This study has been provided to assess the stream water for Tigris River within Baghdad city included five sites Thiraa-Tigris (S1), Al-Muthana bridge (S2), AlShuhadaa bridge (S3), Al-Doraa (S4) and meeting place in the Diyala river (S5) and the study extended to stations south of Baghdad city. Ten parameters of water quality were used in this study, Total Hardness (TH), Calcium (Ca), Hydrogen Ion concentration (PH), Chloride (Cl), Magnesium (Mg), Nitrate (NO3), Sodium (Na), Boron (B), Turbidity (TUR) and Sulfate (SO4). The assessment of water quality for river water was done using three methods, Weighted, Arithmetic, Water Quality Index Method (WA WQI), Canadian Council of Ministry of Environmental (CCME WQI), and the third water quality method developed by Erdenebayar. Overall water quality index by the three methods showed Poor to Unsuitable quality index in Tigris River at Baghdad city except for AlMuthna bridge (S2) was grade good quality index during the time period. From the analysis, it was found that the worst water quality index at the confluence point of Diyala river (S5) and grade unsuitable quality index.
\end{abstract}

Keywords: water quality index, Tigris River, WA WQI, CCME WQI, E WQI.

\section{Introduction}

Water defined one of the most important elements for life and all natural, environment. It is a primary element for industry, a consumer item from human and animals and industrial pollution, as it provides habitat for diverse types of aquatic life in rivers, lakes and oceans, and it covers about $70 \%$ of the earth surface. It constitutes more than 2.5 times that of the earth main land. Also, it is known that the water constitutes about $70 \%$ of the human body. Availability of water resources in countries is a principal factor for the development [1]. in recent years become important to assessment water quality for rivers in advanced countries because they are afraid of surface water decrease [2]. Many decision and efforts have been taken to assess and monitoring quality and quantity for water and analysis results [3]. The assessment quality of water has become important and necessary operations for the protection of water resources, the evaluation is done by the comparison of experimentally determined with local standards [4]. Water quality can be found by analyzing some parameters in water and compared with permissible level to know if can water used for local, industrial and agricultural purposes [5]. Several local and international studies have dealt with the issue of the quality of river water and applications on water quality index equations. Analysis and study of some relevant studies to determine what is required,

\footnotetext{
*Corresponding Author: noor4noor19@gmail.com
} 
what has been achieved, identify the problem, prove the need, determine the importance of this study and its contribution and help in practical development of solutions necessary by decision makers. Jawad et. al., [6] used water quality index to assessment water quality for Dokan lake, Kurdistan, region, by using weighted, arithmetic water quality index, method depended on ten parameters ( $\mathrm{pH}, \mathrm{DO}$, Turbidity, conductivity, Hardness, Alkalinity, Na+, BOD, NO3 and NO2). The results showed that, water, quality of Dokan Lake classified as Good in the five years (1978-2000) and 2008 and as Poor in 2009. khudair [2] assessment of water quality of Tigris river in Baghdad city and suitability for drinking purposes for years 2004 to 2010 by the water quality index was calculated using the Weighted Arithmetic Index method. He depended on The sixteen parameters included: Alkalinity, Calcium, PH, Electrical Conductivity, Chloride, Total Suspended Solid, Nitrate, Orthophosphate, Turbidity, Total Hardness, Magnesium, Sulphate, Iron, Total Solids, Nitrite and Ammonia. The result from this study water quality near Al-Karkh Water Treatment Plant (WTP) was very poor and near Al-Wahda Water Treatment Plant (WTP) was unsuitable. Abbood et. al., [7] Canadian Council of Ministers of the Environment Water Quality Index (CCME WQI) method has been used to assessment Main Drain River in Iraq. Fifteen water quality parameters: (Alkalinity, Nitrate, Chloride, Calcium, Total Dissolved Solid, Electrical Conductivity, Potassium, PH, Phosphate, Sulfate, Total Hardness, Magnesium, Biological Oxygen Demand and Dissolved Oxygen) measured along the main drain river for ten stations from Baghdad to Al-Basrah. The field work was during, the period from 2004 to 2011. The, results, ranged, between 26.6 and 35.5 which, indicate, that river, has the worst, quality, due to effect of various, pollutant, sources. Hamdan et. al., [5] used the Water Quality Index
(WQI) to describe, the level of pollution for Shat Al arab and create WQI map by using Geographic, Information, System (GIS) determine WQI depending on several parameters such as: (Temperature, Biological Oxygen Demand, Nitrate, Total Dissolved Solid, Turbidity, PH, Dissolved Oxygen, Chemical Oxygen Demand, Phosphate, Total Suspended Solid and Electrical Conductivity) for 37 sites along the river to formulate WQI.

\section{Methods}

\subsection{Weighted Arithmetic Water Quality Index Method (WA WQI)}

Water, quality index was calculated by weighted index method for, drinking, purposes. The index, developed, by Tiwari and Mishra (1985) was used. In the present study, ten water quality parameters, namely, $\mathrm{B}^{+3}$, total hardness, $\mathrm{Cl}^{-}$, $\mathrm{Mg}^{+2}, \mathrm{SO}_{4}^{-2}, \mathrm{pH}, \mathrm{Ca}^{+2}, \mathrm{NO}_{3}{ }^{-}, \mathrm{Na}^{+}$, turbidity (TUR), were taken to compute WQI. And the unit weight Wi of each one was obtained depending upon its weight age, by depending the following formula:

$W Q I=\frac{\sum Q_{i} W_{i}}{\sum W_{i}}$

Qi: quality rating scale for each parameter

$Q_{i}=100\left[\frac{V_{i}-V_{o}}{S_{i}-V_{o}}\right]$

$V_{i}$ : estimated concentration of ith parameter in the analyzed water

$V_{o}$ : the ideal value of this parameter in the pure water

$V_{o}=0($ except $\mathrm{PH}=7$ and $\mathrm{DO}=14.6 \mathrm{mg} / \mathrm{l})$

$S_{i}$ : recommended standard value of ith parameter

$W_{i}=\frac{K}{S_{i}}$

Where $K$ : proportionality constant and can also be calculated by using the following equation 
$K=\frac{1}{\Sigma \frac{1}{S_{i}}}$

Classify water quality according this WQI method is show in Table 1 .

Table 1. Water Quality Rating as per (WA-WQI) Method.

\begin{tabular}{ccc}
\hline WQI Value & $\begin{array}{c}\text { Classify of Water } \\
\text { quality }\end{array}$ & Grading \\
\hline $0-25$ & Excellent Water quality & A \\
$26-50$ & Good Water quality & B \\
$51-75$ & Poor water quality & C \\
$76-100$ & Very Poor water quality & D \\
Above 100 & Unsuitable & E \\
\hline From Al-Bayati, 2016,[1] & \\
\hline
\end{tabular}

2.2. Canadian Council of Ministers of Environment Water Quality Index Method (CCME WQI)

The CCME WQI model formulated by Canadian jurisdiction to give the information of water quality for public and management. Moreover, a committee established under the Canadian Council Ministers of the Environment (CCME). This method contains three measures of variance from selected water quality objectives (scope, frequency, amplitude). These three measures of variance combine to produce a value ranged from 0 to 100 (with 1 being the poorest and 100 indicating the best water quality) that rep-resents the overall water quality. Within this range, designations have been set to classify water quality as poor, marginal, fair, good or excellent The measure for scope is $\mathrm{F}_{1}$ (Scope). This represents the extent of water quality guideline non-compliance over the time period of interest
$F_{1}=100\left[\frac{\text { Number of faild Variables }}{\text { Total Number of Variables }}\right]$

The measure for frequency is F2 (Frequency). This represents the percentage of individual tests that do not meet objectives (failed tests).

$F_{2}=100\left[\frac{\text { Number of Failed Tests }}{\text { Total Number of Tests }}\right]$

The measure for amplitude is F3. This represents the amount by which failed tests do not meet the objectives. This is calculated by three steps:

Step1: Calculation of Excursion. Excursion is the number of times by which an individual concentration is greater than (or less than, when the objectives is a minimum) the objective.

When the test value must not exceed the objective:

excursion $=\frac{\text { Failed test value }}{\text { objective }}-1$

When the test value must not fall below the objective:

excursion $=\frac{\text { objective }}{\text { Failed test value }}-1$

Step 2: Calculation of Normalized Sum of Excursion. The normalized sum of Excursion. nse, is the collective amount by which individual tests are out of compliance. This is calculated by summing the excursion of individual tests from their objectives and dividing by the total number of tests (both those meeting objectives and those not meeting objectives).

nse $=\frac{\sum_{i=1}^{n} \text { excursion }}{\text { Number of tests }}$

Step3: Calculation of $\mathrm{F}_{3}, \mathrm{~F}_{3}$ (Amplitude) is calculated by an asymptotic function that scales the normalized sum of excursions from objectives to yield a range from 0 to 100 .

$F_{3}=\frac{n s e}{0.01 n s e+0.01}$

The WQI is then calculated as:

$C W Q I=100-\left[\frac{\sqrt{{F_{1}}^{2}+{F_{2}}^{2}+F_{3}{ }^{2}}}{1.732}\right]$

The classify of water quality for this method is shown in the Table 2 . 
Table 2. Range of Water Quality for Canadian, Council, of Minister of the Environment Method.

\begin{tabular}{cc}
\hline WQI Value & Rating of Water quality \\
\hline $\mathbf{9 5 - 1 0 0}$ & Excellent Water quality \\
$\mathbf{8 0 - 9 4}$ & Good Water quality \\
$\mathbf{6 0 - 7 9}$ & Fair Water quality \\
$45-59$ & Marginal Water quality \\
$\mathbf{0 - 4 4}$ & Poor Water quality \\
\hline From Abbood et. al., 2014, [7]
\end{tabular}

\subsection{Erdenebayar Water, Quality Index Method (E WQI)}

This method used to assessment water quality for surface water by using formulae:

$W Q I=100\left[\frac{\sum_{i=1}^{n} \frac{C_{i}}{P I_{i}}}{n}\right]$

Where:

WQI: Water Quality Index

$\mathrm{PI}_{\mathrm{i}}$ : permissible level of $\mathrm{i}$-th variable

$\mathrm{n}$ : number of variables

$\mathrm{C}_{\mathrm{i}}$ : concentration of $\mathrm{i}$-th variable the classification of water quality types is shown in the Table 3.

Table 3. Water Quality Rating as Erdenebayar Method per Method.

\begin{tabular}{ccc}
\hline WQI Value & $\begin{array}{c}\text { Rating of Water } \\
\text { quality }\end{array}$ & Grading \\
\hline $\mathbf{3 1 - 8 9}$ & $\begin{array}{c}\text { Very Clean Water } \\
\text { quality }\end{array}$ & $\mathbf{1}$ \\
$\mathbf{9 0 - 2 4 9}$ & $\begin{array}{c}\text { Slean Water quality } \\
\text { Water quality }\end{array}$ & $\mathbf{2}$ \\
$\mathbf{2 5 0 - 3 9 9}$ & $\begin{array}{c}\text { Moderately Polluted } \\
\text { Water quality }\end{array}$ & $\mathbf{4}$ \\
$\mathbf{4 0 0 - 5 9 9}$ & $\begin{array}{c}\text { Heavily Polluted } \\
\text { Water quality }\end{array}$ & $\mathbf{5}$ \\
& $\begin{array}{c} \\
\end{array}$
\end{tabular}

Above 600

Dirty Water quality

6

\section{Fieldwork and Data Collection}

As shown in "Fig 1" and geographic location of samples in Tigris River are show in Table 4. Five sampling points take along the Tigris River within Baghdad city. In the field, 0.5-liter samples collected and send to the laboratory for analyzing from river using plastic container and send it to the laboratory. These samples take two times of study period. Water quality and pollution in five sites of Baghdad city observe in those five points since August until December 2019. A number of variables, calcium $\mathrm{Ca}$, total hardness $\mathrm{TH}$, chloride $\mathrm{Cl}$, magnesium $\mathrm{Mg}$, boron $\mathrm{B}$, nitrate $\mathrm{NO}_{3}$, sodium $\mathrm{Na}$, sulfate $\mathrm{SO}_{4}, \mathrm{PH}$, and turbidity must be analyzed as soon after collected of the samples because either change rapidly after samples collection. Devices as shown in Table 5. measured these parameters of pollution.

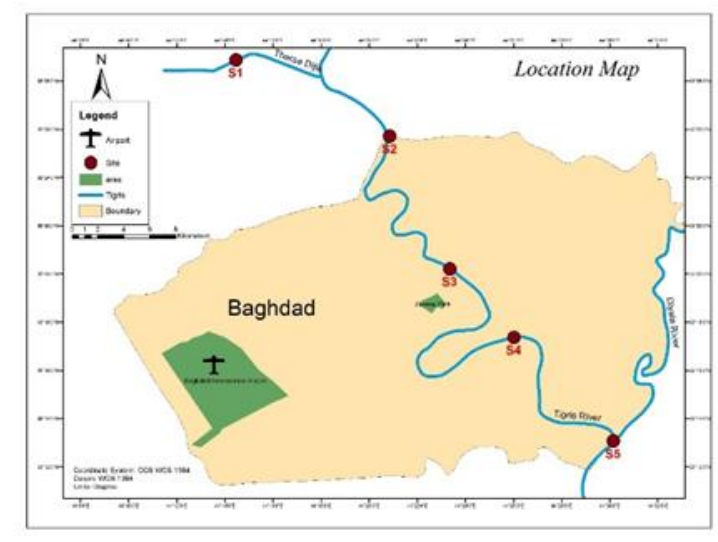

Figure 1 Sites of water samples locations

Table 4Locations of samples in Tigris River

No. Location Geographic location
of

site

Latitudes / North Meridians / east

Grade Minute Grade Minute

\begin{tabular}{cccccc}
\hline S1 & Thiraa- & 33 & 28.887 & 44 & 14.457 \\
Tigris & & & & \\
S2 & $\begin{array}{c}\text { Al- } \\
\text { Muthana } \\
\text { bridge }\end{array}$ & 33 & 25.728 & 44 & 20.842 \\
& & & & & \\
\end{tabular}




\begin{tabular}{cccccc} 
S3 & $\begin{array}{c}\text { Al- } \\
\text { Shuhadaa } \\
\text { bridge } \\
\text { Al-Doraa }\end{array}$ & 33 & 17.369 & 44 & 25.997 \\
S5 & $\begin{array}{c}\text { The } \\
\text { confluence } \\
\text { point of } \\
\text { Diyala } \\
\text { river }\end{array}$ & 33 & 13.073 & 44 & 30.154 \\
\hline
\end{tabular}

Table 5Laboratory measurements.

\begin{tabular}{|c|c|}
\hline Parameters & Method or device \\
\hline Chloride $(\mathrm{Cl})$ & Titration by $\mathrm{AgNO}_{3}$ \\
\hline Total Hardness(TH) & Titration by EDTA \\
\hline Calcium $(\mathrm{Ca})$ & Titration by EDTA \\
\hline Magnesium (Mg) & Titration by EDTA \\
\hline Boron (B) & Spectrophotometer \\
\hline Nitrate $\left(\mathrm{NO}_{3}\right)$ & Spectrophotometer \\
\hline Sodium(Na) & Flame photometer \\
\hline Sulfate $\left(\mathrm{SO}_{4}\right)$ & Titration by EDTA \\
\hline $\mathrm{PH}$ & PH meter \\
\hline Turbidity & Turbidity meter \\
\hline
\end{tabular}

\section{Results and Discussions}

\subsection{Results using Weighted Arithmetic Index Method (WAI)}

Water quality index using method of WAI for Thiraa-Tigris, S1, Al-Muthana bridge, S2, AlShuhadaa bridge, S3, Al-Doraa, S4, and the confluence point of Diyala River, S5 were calculated and found ranged from 44.1 to 125.95 indicate the results revealed from good to unsuitable as shown in "Fig. 2". Station S2 has grade Good at October and November while station S5 at all times the quality of water is Unsuitable because that is where water is dumped from Rustumiya treatment plant and confluence of Diyala river. Other stations have quality of water Poor to Very poor during all of times. "Fig. 3" shows variation of water quality index for stations with time. The figure presented that there is only Good quality in station S2 for a period of two months (October and November). As for the rest of the time, the quality ranges between Poor and Unsuitable. The figure also shows that station S5 has a quality that is Unsuitable for all study time. 

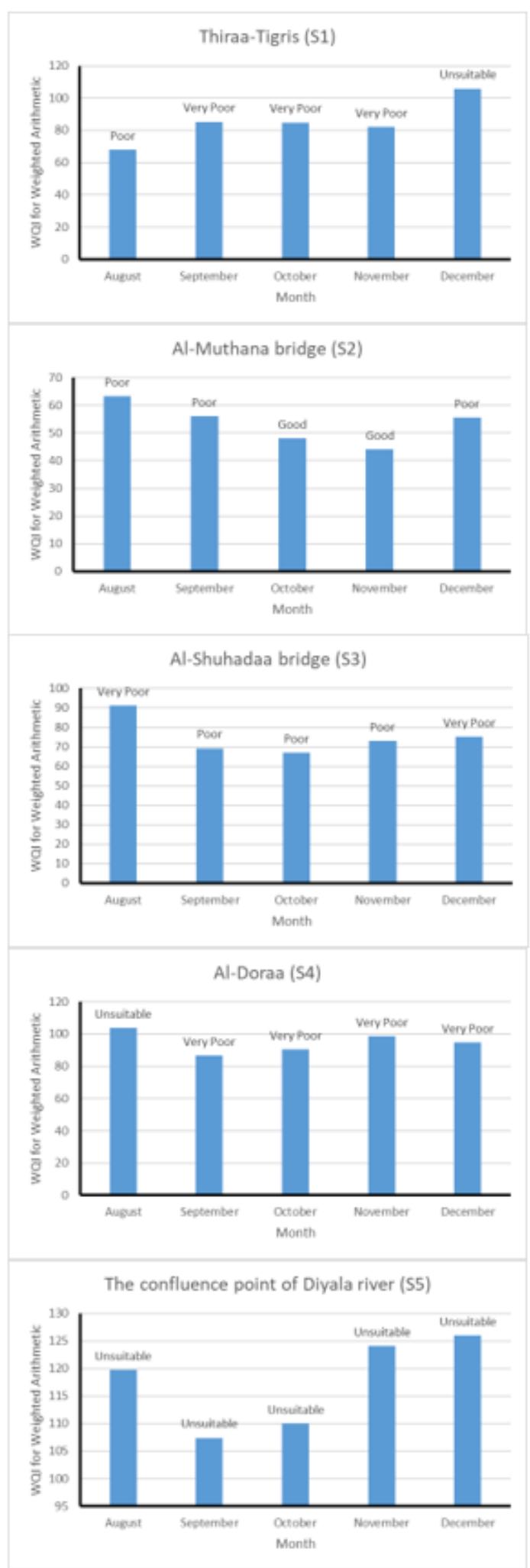

Figure 3 variation of water quality index with time for stations within Baghdad city during 2019 using WA method

\subsection{Results using Canadian Council of Ministers} of Environment method (CCME)

"Fig.4" shows the water quality index in the stations within the city of Baghdad during the study period using CCME WQI. The figure shows that the water quality is good in AlMuthana Bridge, S2 all the time while the rest of the stations range from fair to marginal. This figure also shows that, the water, of the, Tigris, River in the Baghdad region is of poor quality, especially in stations Thiraa-Tigris (S1) and the confluence point of Diyala River (S5). Water quality changes in the stations with the change of time and indicates that the S2 station has good water quality during the study time while the other stations have poor quality water as shown in Fig. 5. These results are the same as in "Fig. 4".

\subsection{Results of Erdenebayer Water Quality index method}

To evaluate spatial variations of water quality by using the method developed by Erdenebayer for all stations at study area, show "Fig. 6". This Figure shows that stations Al-Muthana bridge (S2) and Al-Shuhadaa bridge, S3 have clean water quality all times and Al-Doraa, S4 has also clean water quality only at September, 2019. Other stations S1 and S5 classified slightly polluted water quality during all times. "Fig. 7" shows, as in the previous two methods, that station $\mathrm{S}_{2}$ indicates the quality of clean water, while the other stations indicate bad water. In this method, it is clear that the station $\mathrm{S}_{3}$ is also clean water during the study peroid, unlike the previous two methods. 

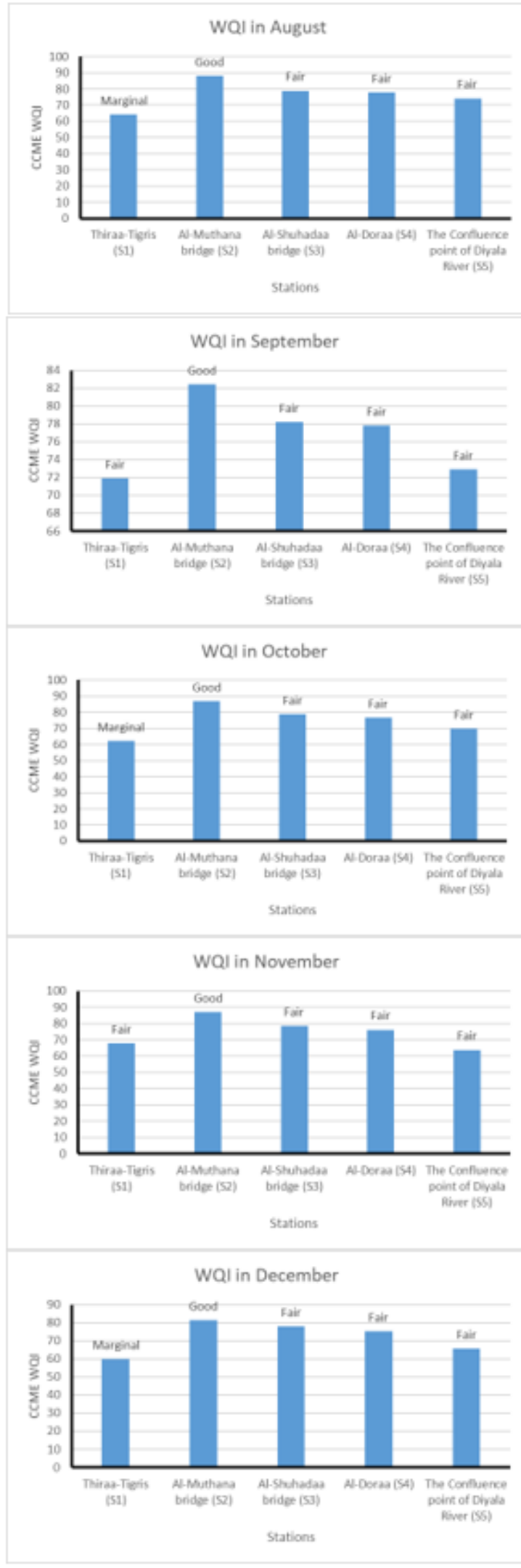

Figure 4 Water quality index within Baghdad city during 2019 using CCME method
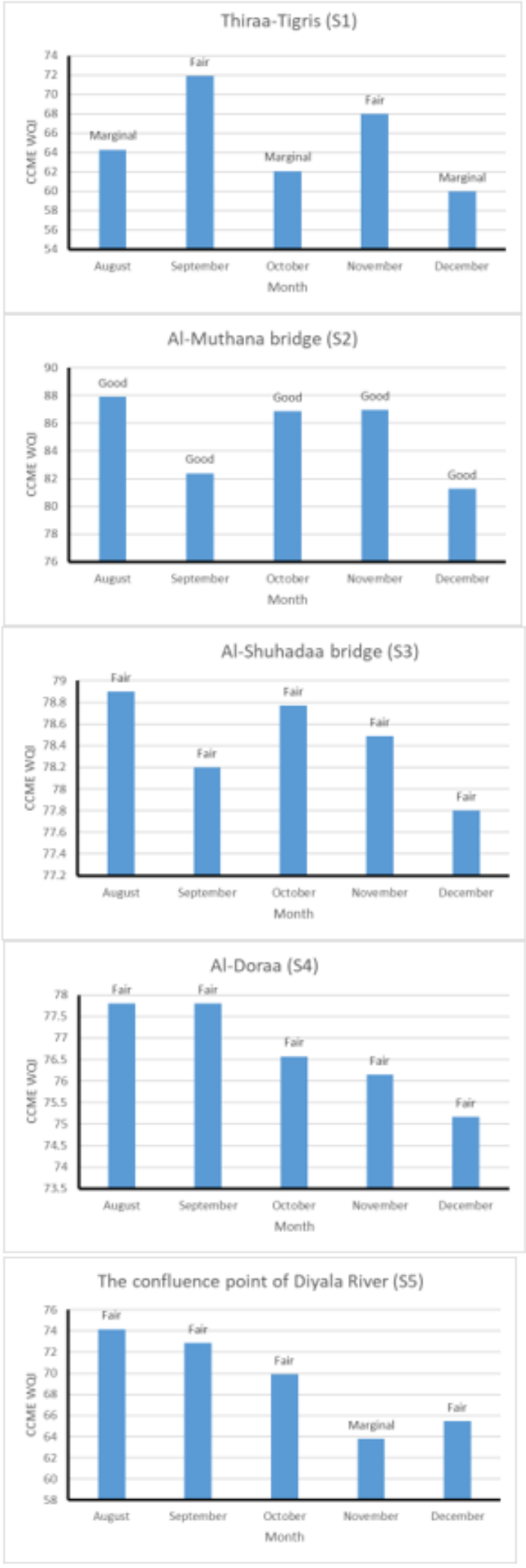

Figure 5 variation of water quality index with time for stations within Baghdad city during 2019 using CCME method 

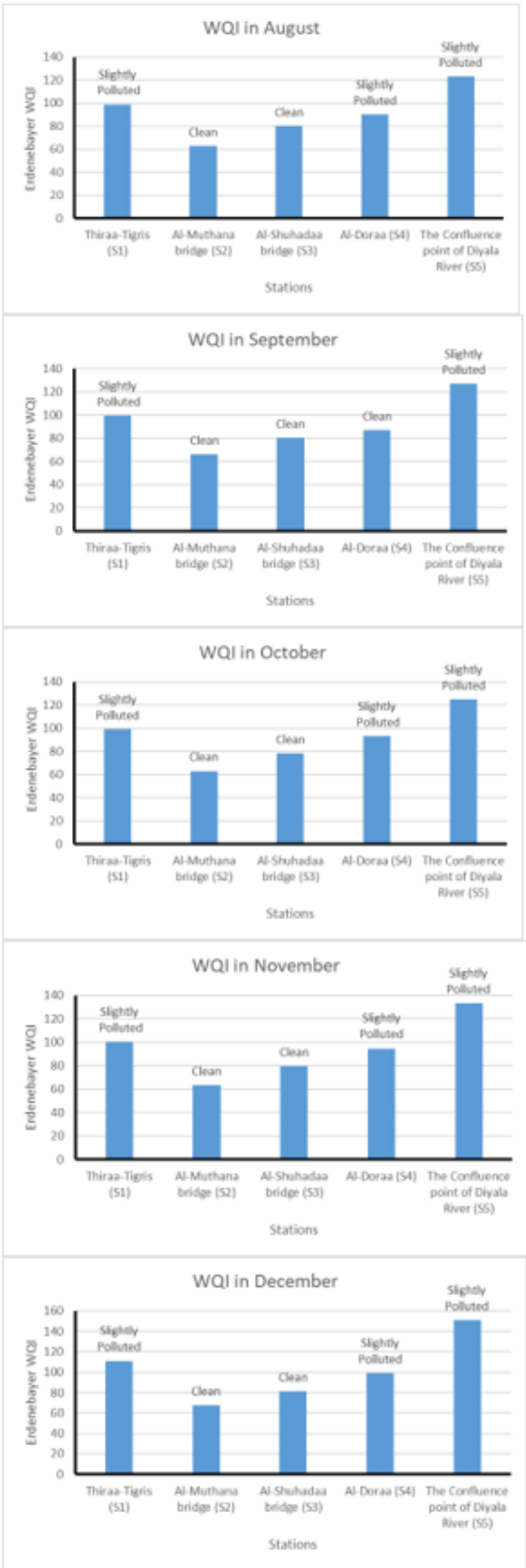

Figure 6 Water quality index within Baghdad city during 2019 using Erdenebayer method
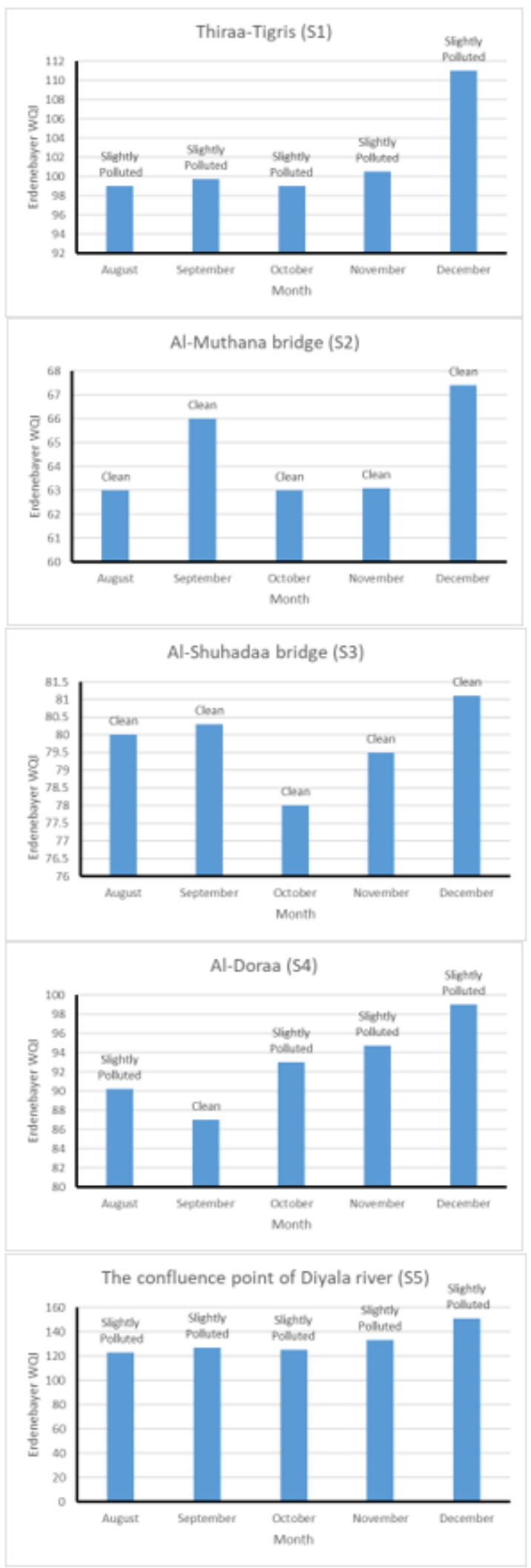

Figure 7 variation of water quality index with time for stations within Baghdad city during 2019 using Erdenebayer method 
"Figs. 8" and "Fig. 9" present the difference quality class ( 1 to 5 ) during, the study period in the river. Rendering the ordering system of each methods water quality from 1 to 5 where class 1 appear the best water quality level (Excellent or very clean) and class 5 indicates to the worst one (unsuitable, poor or heavily polluted water quality). The figures shown that main discrepancies, are recorded in the qualitative, ordering, among, the individual, systems. More specifically, the three methods presented that station S2 has classified good or clean water quality at two months October and November as previously concluded in this study while the two methods, CCME and Erdenbyar give the same results (good or clean) during all months of measurements. "Fig. 9" shows constant quality class all months on class 5 (unsuitable) for Weighted Arithmetic method and on class 3 (fair) for the other two methods. In general, we said Weighted Arithmetic indicates higher values of quality class, because this method has included all values of parameters of water quality and calculation in special mathematical equations to give the quality of water in number has named water quality index and is more appropriate to surface water for human use.

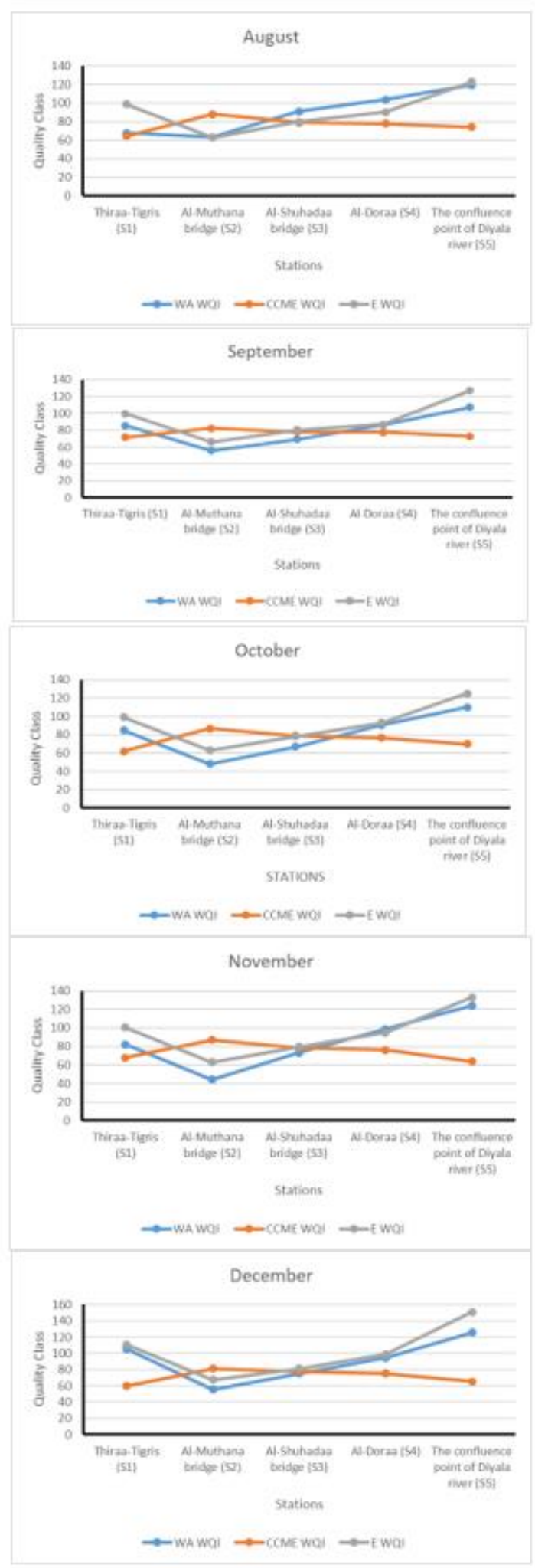

Figure 8 variation of the quality class in Tigris River for three methods during 2019 

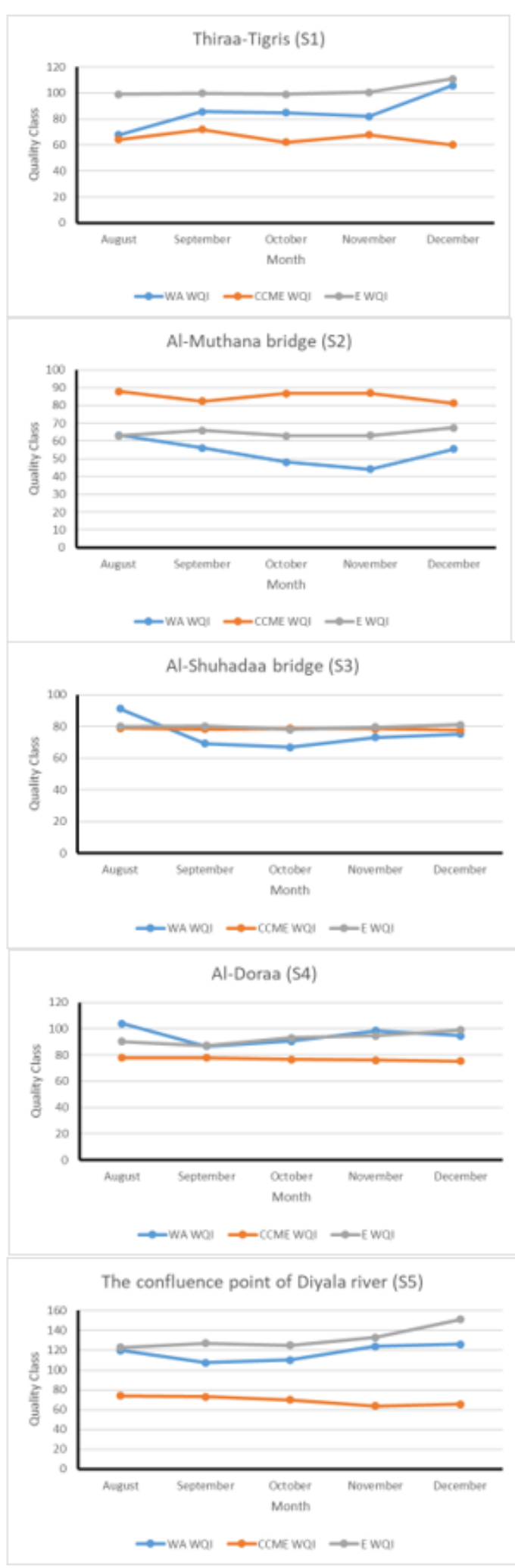

Figure 9 variation of the quality class in Tigris River for three methods during 2019

\section{Conclusions}

Based on the overall results analysis of this study, the following conclusions are extracted:

1. Weighted Arithmetic Index method

a. Water quality index of Tigris River in all of the sampling sites found poor to unsuitable grade during August, September and December 2019 while this method gives good water quality index for station $\mathrm{S}_{2}$ during only two months October and November 2019.

b. Station $\mathrm{S}_{5}$ always has an unsuitable water quality index for the entire study period.

c. Weighted Arithmetic indicates higher values of quality class, because this method has included all values of parameters of water quality and calculate in special mathematical equations to give the quality of water in number has named water quality index and is more appropriate to surface water for human use.

2. CCME WQI

a. The Canadian WQI, for, the, stations of the Tigris, River was classified as fair (60-79) except for $S_{2}$ which was classified good (80-94) during the study period and Marginal for $\mathrm{S}_{1}$ during December, 2019.

b. CCME WQI calculated water quality index as excellent in Al-Muthana Bridge $\left(\mathrm{S}_{2}\right)$ and Al-Shuhdaa Bridge $\left(\mathrm{S}_{3}\right)$ during 2009.

3. Erdenebayar Water, Quality, Index

a. Water, quality, index developed by Erdenebayer method revealed that stations $S_{1}$ and $S_{5}$ were worst water quality and grade slightly polluted at time of study.

b. The results of water, quality, index showed that, the level of Tigris, River, in stations $S_{2}$ and $S_{3}$ is clean and classified in class 2 .

The three methods presented quality of water in Tigris River increased in pollution started from 
Baghdad to south it because there are many activities

4. contribute to river pollution such as industrial, commercial and residual activities. Sewage treatment plant is one of the point source contributing pollution to Tigris River.

\section{Acknowledgements}

Authors would like to express their grateful to the college of Eng./Mustansiriyah University for her back up to carry out the present work.

\section{Conflict of interest}

There are no conflicts to declare

\section{References}

1. Zahraa. M. K. Al-Bayati, (2016). "Water Quality Index in Shatt Hilla River Using Spectral Radiometer Techniques”, M.Sc. Thesis, University of Technology, Iraq.

2. Basim. H. khudair, (2013). "Assessment of Water Quality Index and Water Suitability of the Tigris River for drinking water within Baghdad City, Iraq". Journal of Engineering, vol.19, no.6.

3. Koklu. R., B. Sengorur, and B. Topal. (2010). "Water Quality Assessment Using Multivariate Statistical Methods-A Case Study: Melen River System (Turkey)". Water Resources Manage, vol.24, pp.959978.

4. Debels, p., Figueroa, R., Urrutla, R., Barra, R., and Niell, X., (2005). "Evaluation of water quality in the Chillan river (central Chile) using physicochemical parameters and modified water quality index". Environmental Monitoring and Assessment, pp.301-322.

5. Sargaonkar A. and V. Deshpande, (2003). "Development of an Overall Index of Pollution for Surface Water Based on a General Classification Scheme in Indian Context," Environmental Monitoring and Assessment, vol.89, no.1, pp.43-67.

6. Abdul Hameed M Jawad, A., Haider S, A., \& Bahram K, M, (2010). "Application of water quality index for assessment of Dokan lake ecosystem, Kurdistan region, Iraq". journal of water resource and protection.

7. DheyaaW. Abbood, KarimR. Gubashi, \& HananH. Abbood, (2014). "Evaluation of Water Quality Index in the Main Drain River in Iraq by Application of CCME Water Quality”. Civil Environ Res, vol. 6 no. 8 .

8. Hamdan, Ahmed, Ammar Dawood, and Douaa Naeem. (2018). "Assessment study of water quality index (WQI) for Shatt Alarab River and its branches, Iraq. " MATEC Web of Conferences. Vol. 162. EDP Sciences.

9. Altansukh, Ochir, (2008). "Surface Water Quality Assessment and Modelling A case study in the Tuul River, Ulaanbaatar City, Mongolia." ITC. 